\title{
ALK wt Allele
}

National Cancer Institute

\section{Source}

National Cancer Institute. ALK wt Allele. NCI Thesaurus. Code C51738.

Human ALK wild-type allele is located within 2p23 and is approximately 729 kb in length.

This allele, which encodes ALK tyrosine kinase receptor protein, plays a role in brain

development and exerts its effects on specific neurons in the nervous system. 